\title{
RESTRUCTURING (IN)TANGIBLE CULTURAL HERITAGE OF RURAL ZIMBABWEANS: SUSTAINING AND FULFILLING LIVELIHOODS
}

\author{
Jerry Rutsate ${ }^{1 *}$ and Sipho Heleni Rutsate ${ }^{2}$
}

*Corresponding Author: -

\begin{abstract}
: -
The documentation and promotion of African experiences grew out of the need to mitigate the weaknesses of the oral tradition through which the history of the presumed complex indigenous African creative undertaking was defined. The paucity of written records was further accentuated by the 2003 UNESCO Convention for Safeguarding Intangible Cultural Heritage. The methodical essential tools of accurate collection and critical analysis were deemed to be the better organized forms of freezing experiences. Skewed towards the sciences, research on both pre and post-independent Zimbabwean indigenous intellectual property has not yielded much benefit to the researched practitioners. To this end, Higher Education has failed to fulfil society's expectations for pace-setting development and sustainability. In the stir of the world-wide decline of industries owing to trade liberalization and the development of free market as well as the adoption of the European Union 'high-road competitiveness' policy (Aiginger 2014), this chapter intends to reground creative and cultural industries by embracing a potential symbiotic relationship between informal transmission of authentic (in)tangible cultural heritage and the formal living archiving and commodification of the indigenous knowledge systems of ethnic groups of people in Zimbabwe. The case study for this paper, which commenced in 2015, is the Dzimbadzamabge Cultural Heritage Enterprise Institute located in Nemamwa Rural District.
\end{abstract}

Keywords: - Oral tradition, cultural heritage, sciences, liberalism, living archive, commodification, sustainability

\section{(a) $(\$)$}




\section{INTRODUCTION}

The diverse and rich natural and cultural heritage of Africa (Abungu 2019) which is intertwined in the majority of its rural inhabitants' fabric of life stands in stark contrast to the topical issues; chief among them: poverty, hunger and poor health services associated with Africa. The United Nations Department of Economic and Social Affairs Millennium Development Goals' report on Africa covered matters of concern pertaining to health, hunger and limited opportunities to pursue education by stating that: $70 \%$ of Sub-Saharan African population still suffers from lack of access to improved sanitation; $41 \%$ of its inhabitants still live with less than $\$ 1.25$ per day, and out of the 57 million global out-of-school children of primary school age, 33 million are in Sub-Saharan Africa (UN MDGs 2015). With its plan of action on people, the planet and prosperity, the UN 2030 Agenda for Sustainable Development intended to transform our world takes note of the need to provide focused and scaled-up assistance to least developed countries and other countries in special situations, in line with relevant support programmes (UN 2015). In Sub-Saharan Africa, sustainability is informed by practical experience and not scientific knowledge, even though the former has been politically and ideologically marginalised (Hountondji 2002). We view the provision of assistance as a short term intervention which would not result in the beneficiaries' prosperity. We contend that African cultural heritage refers to those tangible and intangible legacies due to human practices which are of significance to our understanding of past societies (Msemwa 2005) and also that our culture and heritage are the springs from which we metaphorically drink the living waters that give us the strength to succeed in our endeavours (Magwa 2019). Accordingly, the quality of African life can only be improved when we become fully conversant with how to deploy culture and heritage as the fundamental requirements underlying our education and national development (Ibid 2019).

African history in general and indeed, the history of Zimbabwe can never be fully comprehended without paying attention to external forces that impacted on the quality of life of its indigenous population. To this end, the United Nations Educational Scientific and Cultural Organization's project on reconstructing Africa's history has been carried out so as to try to free it from racial prejudices ensuing from slave trade and colonization, and promoting an African perspective (UNESCO 2019). Given that much of Africa's history denotes colonial occupation and dominance by Europe, colonialism in Africa provided the framework for the organised subjugation of the cultural, scientific and economic life of many on the continent by ignoring indigenous knowledge systems and impacting on African people's way of seeing and acting in the world (Higgs 2008). Thus, this paper aims to develop a framework for the establishment of a nuanced study of Zimbabwe's natural and cultural heritage. The dialogue and intercourse that has led to this paper's offer of the AfriZimcentric Heritage Resilience $(A Z H R)$ framework to cultural heritage restructured education through the use of indigenous languages as media of instruction and contextualized learning (Magwa 2019) draws from the problem of heritage education that has seen more and more people losing the opportunity to acquire depth of knowledge of their heritage due to education that could be neither effective nor contextualized to the needs and preferences of its clients (Mendoza et al 2015).

\section{AfriZimcentric Heritage Resilience Framework}

The $A Z H R$ framework is a thoughtful, experiential and collaborative educational paradigm which was constructed by the authors of this paper. It is meant to provide lasting solutions to the multifaceted problems engulfing the lives of the majority African indigenes. This framework is characterized by African perceptions that incorporate humanity (Unhu/Ubuntu), holistic worldview, generational memory narratives, theory in practice, spiritually driven relationship between nature and culture, contextualized acquisition of knowledge and skills as well as the use of an interdisciplinary and intersubjective approach to creative and innovative enterprises for sustainable development. Unhu/Ubuntu can be defined as a moral and epistemological theory that has been claimed to inform the moral habits of Africans South of the Sahara (Zimunya, Gwara and Mlambo 2015). The African philosophy of Ubuntu is typically characterized as a communitarian philosophy that emphasizes virtues such as compassion, tolerance and harmony (West 2014). On the contrary, the disintegrating global moral fabric, which is drawing increasing attention, has had devastating consequences in countries developed and developing, large and small, market-oriented or otherwise, because of accusations of corruption, governments have fallen (IMF 1998). It is our belief that the AZHR's Unhu/Ubuntu reach of resilience will encompass the ravaging corruption reported by Transparency International Corruption Perceptions Index which marked Zimbabwe at 22 on a scale of 0(highly corrupt) to 100(very clean), (TICPI 2016). The shocking and damaging recent example of corruption across Europe, the Middle East and Africa region that almost half of all workers think bribery and corruption are acceptable (WEF 2019) can be partially mitigated through a heritage-based educational programme that upholds virtues of Ubuntu. When asked to describe Africanness from a Karanga perspective, the Dzimbadzamabge community spirit medium and performing expert notes in ChiKaranga translated into English language that:

ChiKaranga is a diverse concept. This complex concept is called ethos. Examples of ethos are idioms such as: A single finger cannot kill lice or one man cannot surround an ant hill. The strength of the fish is in water. Ideas are shared. One who does not take advice will land oneself in trouble. Plenty translates to rewards, and One who you rear will in turn rear you. (Dengu 2020).

Drawing from Dengu's definition of Karanga philosophy of life supported by the authors of this chapter's lived experiences, we argue that African humantarian ethos embracing moral ideals incorporating unity in diversity, love and virtue lay the foundation for the establishment of sound relationships among beings and their environment. For example, the relationship between the humans and animals of the veld is cemented through the use of totems where, for instance, if one's totem is hove (fish), fishes become esteemed to the extent that they would not be eaten by the totem holders; the corollary being the conservation of such species. An analogy to this purview is that: 
One of the earliest books to provide snippets of the richness of southern African heritage is the diary of Mangena Fuse. Wriiting in isiZulu whilst teaching near Eshowe, he described how smoke from a small fire made from grass and dung was used to protect trek oxen from tsetse flies. At the landscape level, this small window on situated knowledge practices opens up insights into how the grasslands of eastern southern Africa were not only shaped by natural processes like lightining strikes, but by the heritage practices of early cattle peoples to maintain pasture quality and decrease risk. Unfortunately, there are few texts that provide these insights, as most early southern African literature is dominated by colonial narratives. (O’Donoghue et al 2013).

The southern Africans' wisdom of including multiple perspectives to the management of economic, political, health and societal challenges pertaining to protection, conservation, valorisation and interdependence is a uniquely African perception to the convergence of their functional natural and cultural heritage. In essence, the Karanga view animals (mhuka nezvipuka), and other physical phenomena which include, but are not limited to, mountains (makomo), caves (mapako), forests (masango), water bodies such as springs (zvitubu), pools (madziva) and seas (makungwa) as symbolic forms of the presence and existence of the forceful spirit beings that help their siblings to enforce the apprehension of the conventional ethical and moral principles and practices upon which the humans out to anchor their lives. This perception can be exemplified through the two selected examples: one about a burning mountain (gomo rinotsva), and the other on clothes (zvipfeko) hung to dry close to a spring of water. The uninstigated burning of a reverred mountain would signify that, for as long as the fire would not be forced to quench, rain would fall, not only to stop the fire, but to replenish the veld and enhance human livelihoods. It has been customary to seldom find clothes hung to dry close to a spring of water where those who would get there to fetch water would neither be expected to take them nor pass a comment about them, lest the spring would swallow them. This wisdom entails the ethical and moral lessons that it is unethical to take what does not belong to one and that one should learn to hold in confidence information which need not be shared. We, therefore note that the said natural phenomena characterise the statures, voices and gestures of the beings who reside in the spiritual realm. Thus, African religion permeates all departments of life so completely that it is not possible to isolate it (Mbiti 1969). Embedded in Karanga epistemology is the spiritual power that impacts the whole of life which manifests itself through the elders acting as repositories of sacred traditions who are bound by higher moral imperative to be accountable to the community and their eternal ancestors (Mageza 1979). Such is the knowledge system that indigenous people the world over have, over time, developed to guarantee continued survival (Mawere 2015).

Essentially, the constant conduct of spiritual ritual ceremonies among the Karanga in order to venerate their ancestral spirits undersores the three-pronged perception to the African worldview wherein the humans regularly employ musical performances meant to entice their ancestors to embody the spiritually initiated social actors to voice mitigatory measures to the challenges of life they are incapable of handling (Rutsate 2010). To this end, African life experience and indeed the indigenes of Zimbabwe's beliefs and practices have been punctuated by creative and performing arts. A typical example is that of Sub-Saharan Africa:

The historical consciousness of sub-Saharan Africans, which has largely been transmitted through their material and symbolic as well as intangible cultural heritage including drawings, paintings, sculpture, song, dance, drama, poetry, storytelling, proverbs, idioms, games, and folktales has been upheld for its perceived relevance to present and future lives. (Rutsate 2019)

We concur that all visible and invisible phenomena in African thought have life given by God the Creator and driven by divinities, spirits, ancestors and then humankind, animals, flora, fauna and other minor forces, each reinforcing each other (Rettova 2016). The self in African culture is inseparable from the world since it is consonant with the social and natural environment (Idang 2015). A more expanded supportive perspective to African cultural and natural heritage is that all heritages contain both tangible and intangible elements which are social, cultural, physical, material and emotional, all of which cannot be disconnected from each other (Munjeri 2004). As such, the African reality of life is a complex concept that incorporates yet another fundamental element of the spiritual dimension wherein the ways of living, believing, healing and celebrating are interwoven through the partnership of nature and culture (Abungu 2019). Thus, the symbiotic relationship between humans, their environment and spiritual beings has often been expressed through terminologies embodying diversity, holistic, embodiment, functionality and valorization, among others.

In recognition of the fact that diversity can be conceived from various dimensions, we categorise African diversity in two: ethnic, and linguistic. The African continent is inhabited by a multiplicity of ethnic groups of people. The indigenous ethnicities in Zimbabwe include the Kalanga (mainly located in Plumtree, Matebeleland South Province), Karanga (Masvingo, Midlands South), Korekore (Mashonaland Central), Manyika (Manicaland North-East), Nambiya (Matebeleland North), Ndau (Manicaland South), Ndebele (Bulawayo, Midlands North), Shangwe (Midlands North), Tonga (Matebeleland North), Vhenda, (Matebeleland South), Xangana (Masvingo South-East) and Zezuru (Harare, Mashonaland East and West). The languages which are spoken by these ethnic groups are: TjiKalanga, ChiKaranga, ChiKorekore, ChiManyika, ChiNambiya, ChiNdau, IsiNdebele, ChiShangwe, ChiTonga, XiVenda, XiXangana and ChiZezuru, respectively. 


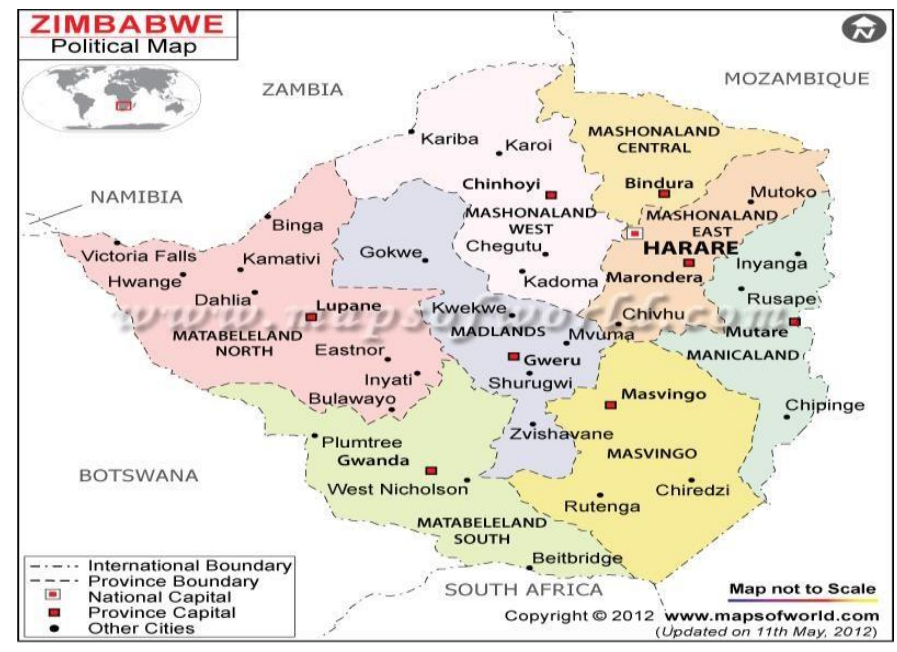

Google Map of Zimbabwe Provincial Boundaries

Despite the fact that there is a lot in common with regards to the ways of living, values and worldview, which typifies the Africanness of the ethnicities outlined in the foregoing paragraph, the peculiarities of the same is chiefly evident in the humanness of belonging to a community and in so doing participating in the beliefs, ritual ceremonies, festivals and the incorporation of other creative and innovative forms of expression encompassing performing arts - songs, dances, instrumentation, props, costumes, games, folktales as well as fine and visual arts (Wamue 2001).

It can therefore be argued that the African philosophy embedded in its exponents' heritage provides a framework for the transformation of educational discourse in Zimbabwe since it recognises diversity, upholds lived experience and challenges Western Eurocentric hegemonic forms of universal knowledge (Higgs 2008). A Dzimbadzamabge community member, spirit medium, rain priest, herbalist and performing expert, as if to propose an indigenous educational framework, narrates his views in ChiKaranga which have been translated into English language as follows:

Even though I did not advance much in the coloniser's school education, my ambition, in agreement with the majority who reside in Chief Mugabe's area of jurisdiction, is that the experts in our cultural heritage become teachers and lecturers who teach in vernacular. Over the past many years, I imparted some knowledge about our cultural heritage to both students and their lecturers from institutions of higher education undertaking research and documenting their findings in English for the benefit of the elite and white audiences. In addition, I have been consulted by many national and international patients suffering from all sorts of ailments and I treated them to recover fully. There are many from among us who possess knowledge and skills in utilising the visible and invisible phenomena to sustain livelihoods. For example, expertise in making fire lighters and blast furnaces for making tools such as hoes and axes out of iron and steel. Those of us with sound understanding of our heritage have a problem in that we are viewed as unlearned because it is the Western scientific knowledge system which is perceived to be the only true knowledge that sustains the economies of all people worldwide. Such perception is what led us to be a poverty stricken people. Thus, our vision is to wage another war of liberating our minds by furnishing them with the knowledge of our cultural heritage with the support of the well-groomed literate spearheading research and documentation of our cultural heritage in vernacular to be used as resource materials by the Dzimbadzamabge Cultural Heritage Enterprise Institute. We perceive this as a way to protect our intellectual property for our enrichment and also make known our identity across the world and become global partners. (Mushipe 2020).

Many questions pertaining to cultural heritage including - What is cultural heritage? Why should we bother ourselves to talk about cultural heritage? Whose cultural heritage is worth studying? How can cultural heritage be safeguarded? Can cultural heritage be embraced for sustainable development? - have been tackled in academic debates and organisational conferences and workshops out of which numerous ideas have been offered. When crystallised, Mushipe's opinions about Karanga heritage in particular and the Zimbabwean heritage in general is that heritage is an indispensable tool for identity and emancipation. This claim is substantiated by the assertion that the culture of a people is what marks them out distinctively from other human societies in the family of humanity (Idang 2015). The African Union as the voice of its populace, envision a visible, supple and self-reliant continent. Its three goals and objectives of the Agenda 2063's strategic framework for inclusive and sustainable development, namely i) Africa with a strong cultural identity; ii) An African whose development is people driven, relying on the potential offered by African people, and iii) An Africa as a strong, united, resilient and influential player and partner (AU 2013) are comprehensively mirrored in the views of the Karanga of the Mugabe community as expressed by Mushipe. We hold the view that the initial step on a trajectory to operationalise this vision which connects well with what Mushipe propounds. To this end, we offer an AfriZimcentric Heritage Resilience model which embodies a holistic approach to imparting indigenous Zimbabwean cultural civilisation. This is strongly supported by the features on the Institute site incorporating a moutain, caves, thickly grown vegetation with a lot of herbs, a field for growing small grain crops, built environment embodying the infrastructure of an indigenous Karanga homestead, community shrine, open-air performance arenas, children's play centres and other buildings which will serve as classrooms, working spaces and archives. Accordingly, the site provides a conduce environment for conveying the holistic heritage of the innovative and iconic Dzimbadzamabge Institute in ChiKaranga and the equivalent translations in other Zimbabwean ethnic languages. The involvement of other cultural knowledge owners and artefacts experts in the 
Dzimbadzamabge Institute activities guarantees the replication of the project to ethnic communities other than the Karanga of the Dzimbadzamabge community.

\section{European Epistemology Shortfalls Overcome}

The colonisation of Africa by Europe in general and Zimbabwe by Britain in particular, accounts for a brief examination of the European philosophy so as to underscore the discussion of its hegemonic impact on the colonised. The term epistemology is a construction from two Greek terms, episteme and logos, which mean understanding and claim, respectively. Epistemology is the philosophical study of the nature, origin and limits of human knowledge that is sometimes referred to as the theory of knowledge (Stroll 2020).

Essentially, this definition together with many others like it, emphasize the fact that philosophy is a product of human thought about the power of the human intelligence to make sense of and use language to assign meaning to the material universe. The version of humanism which was propelled by the epistemology adopted by Europe in the $16^{\text {th }}$ century is traceable to the late Middle Ages era which was characterised by several crises, chief among them: the exponential population growth enhanced through trade aided by technological advancement; the disintegration of authority from empires to politically separate dynasties, and the religious turmoils. These revolutions and reforms did not only compel great thinkers who were subjected to them to reason out solutions for them, but they also reshaped society and economic life, ushered in state power, enhanced intellectual life, technology and military. As such, what was known as philosophy prior to this turning point in European history became the discipline of science (Brush 2019). This science of the $16^{\text {th }}$ and $17^{\text {th }}$ manifests:

Out of the fervent of the Renaissance and Reformation there arose a new science, bringing about the following transformations: the reeducation of common sense in favour of abstract reasoning; the substitution of a quantitative for a qualitative view of nature; the view of nature as a machine rather than as an organism; the development of an experimental, scientific method that sought definite answers to certain limited questions couched in the framework of specific theories, and the acceptance of new criteria for explanation, stressing the 'how' rather than the 'why' that had characterised the Aristotelian search for final causes. (Ibid 2019).

The hallmark of the constricted perception of the science outlined by Brush is the emergence of the $19^{\text {th }}$ century political and economic Liberalism in Europe. In essence, scientific revolutions in general and liberalism in particular, are positions that are laden with numerous difficulties in identifying and conceptualizing scientific revolutions involving many of the most challenging issues in epistemology, methodology, ontology, philosophy of language and even value of theory (Nichles 2019). The Eurocentric scientific knowledge system became an organized way of subjugating African indigenous knowledge systems as substantiated by some African scholars who maintain that the dominance by Euro-Western epistemology, of African development is drowning in reductionist and secular ideologies that dismiss the cultural and spiritual realities of African people (Mbiti 1969, Nyamnjoh 2001 and Lebakeng 2010). By overtly denigrating indigenous African knowledges and worldviews as obstacles to development, the epistemology, ontology and axiology of reductionist and positivist development remains incoherent and meaningless to African people by way of its rejection of the very essence of indigenous African life; a spiritualised relationship to the universe (Olupona 2015).

The political and economic events that unfolded subsequent to the Pioneer Column's mission are that:

From the collapse of the first concerted African armed resistance to British colonisation in 1896-7 until the creation of the political and economic bloc known as Rhodesia and Nyasaland in 1953, Southern Rhodesia went through tremendous economic and political changes that established a modern state and changed the way in which the African majority lived. (Mlambo 2014).

The Pioneer Column destroyed the Ndebele State at the end of the $19^{\text {th }}$ century and Rhodes claimed Zimbabwe (then Rhodesia) for the British. The colonial society was subjected to an autocratic rule and a capitalist economy. From an economic perspective, capitalism coupled with neoclassism dictated the commodification of goods and services by way of exploiting what predominantly ought to be communally owned such as wealth, human resource, natural and cultural heritage. By extension, this economic system brought with it the comparative and competitive edge through mechanisation and industrialisation that elbowed subsistence farming and handcraft endowments of the indigenes, notwithstanding several millennia of indigenous knowledge practices which had been fundamental to sustaining indigenous livelihoods (Muller 2012). In his Chikaranga outline of the colonial dictates on the people who inhabit his area of jurisdiction, translated into English language, the Karanga Chief says:

My late grandfather who lived for about hundred and twenty years used to tell me the way the colonisers treated them. Chief among them: They were sent away from their traditional villages with rich loam soils to designated settlements with predominantly sandy soils. Their wealth, particularly numbers of cattle were reduced through forced sales to match the new restrictive settlements. Hunting wild animals was prohibited. They were driven to grow cash crops in instead of the usual small grains for their staple food. They were prohibited from cutting down trees and encouraged to grow gum trees. They were used as cheap labour on the farms owned by the whites. They were converted to Christianity. Schools in which European culture was taught were imposed on them. Our Territorial Mountain Shrine Great Zimbabwe Monuments (formerly Zimbabwe Ruins) was forcibly taken from us. In my conception and experience of life, all that I learnt has led me to consider the majority Karanga life as a mirror image of European culture. (Mugabe 2019).

Our interpretation of Mugabe's narrative incorporates both the review of related literature and our life experiences. The forced resettlements of indigenous Zimbabweans, which was enforced by the British Land Apportionment Act of 1930, had immense social and economic repercussions on the indigenous victims. For example, the majority of the resettled Karanga had large herds of cattle that would not have enough grazing land in the newly apportioned pastures were forced 
to surrender to the colonial masters the excess numbers from the stipulated quota per household. The victims did not only suffer loss of their hard earned material wealth, but their alienation from symbolic phenomena such as shrines and the graves of their ancestors tortured them psychologically, especially when they saw some excavated skeletal remains of their deceased ancestors being used as ash trays by their masters while they worked for no pay on farms. The popularly grown finger millet (rukweza), sorghum (mapfunde) and pearl millet (mhunga) were the most common variety of small grain crops that were cultivated in suitable whether conditions, not only for food security, but also for sustained release health reasons. The British colonists did not consider these crops as cash crops and discouraged their cultivation causing a huge nutritional and physical activity transition that may have resulted in several Africans suffering from Non Communicable Diseases (NCD)s that are rising faster than other pandemics like HIV/AIDS. This claim is partially supported by the African Office which reported that there is a decreasing life expectancy (59 years) values in Zimbabwe (WHO 2016).

We argue that the total disregard of the code-named 'barbaric' African knowing and experience led the colonists to refer to the present day Great Zimbabwe Monuments as the Zimbabwe Ruins. Under normal circumstances, a ruin would be worthless; but in this case, it turned out to be an exploitative strategy for establishing an attractive and fortified cultural tourism industry. The worth of the Ruins was affirmed by its listing as a world heritage wonder of outstanding value (UNESCO 1986). Lamenting on the loss to the colonial government of their esteemed civilisation, the Mountain heritage (Dzimbadzamabge) from which the name of the country Zimbabwe was driven, a Karanga culture authority and performing expert states:

After the colonists had confisticated our Mountaion and fenced it in order that they commercialised it, they came round to rope us in their project as free labour to entertain visiting tourists through our indigenous musical arts. They took us for beggars to well wishers because they did not pay us anything. This was a way of exploiting the cultural knowledge and practices of the people they harshly despised. (Chakawa 2019).

The epitome of the rapid political, economic and social changes that the British brought to bear on Zimbabwean Africans were fostered through the system of education which focused on furnishing its clients with requisite knowledge and skills to enter the job market. The introduction of a pervase and deeply held white supremacy formal education system for Sothern Rhodesian Africans was meant to privilege the whites while limiting African development (Hungwe 1994). The establishment of farms, mines, manufacturing industries and the commercial sectors of business necessitated the training of the human resource to drive economic growth. The schooling system that was instituted for Rhodesia (now Zimbabwe) was founded on the Rhodesian Education Ordinance Number 18 of 1899 which comprised the segregation of schools according to races wherein African education was fully delegated to Christian missionaries. African education assumed that Africans were in a barbaric state, without writing and without the use of the simple wheel, thus, Africans in Southern Rhodesia were apathetic about western schooling (Parker 1960). The evidence to this fate lies in many schooled Zimbabweans who have been offered jobs in the diaspora, particularly in Europe and the the United States of America as well as the overwhelming redundancy of higher education graduates who fail to secure jobs due to the collapse of the Zimbabwe industry, particularly in the aftermath of the 2000 fast track land reform. The time came when the extensive capture involving oppression (hudzvanyiriri), exploitation (hupambe pfumi) and segregation (rusarura ganda) culminated into a revolution: the 19651979 guerrilla war of liberation (hondo yerusununguko) which was waged against the colonial rule. This liberation war has tended to also take the coloniser's narrow line of thought by focusing on the recapture of the physical space; the land.

The 2003 UNESCO Convention for the Safeguarding of Intangible Cultural Heritage, to which Zimbabwe is a signatory, has played a pivotal role in raising an awareness on the need to manage cultural heritage as an incentive for sustainable economic development. It is saddening to notice that, forty years into its existence, the Zimbabwe government has maintained an education system of the sanitised version of Western classical tradition while paying lip service to indigenous cultural heritage. Deeply concerned by the manner in which the government of the day has conceived and utilised heritage at national level, some indigenous Zimbabwean scholars observe that the outdated and out-of-context heritage legislation, which is deeply rooted in colonial philosophy, enables it to legally own heritage which practically belongs to the people (Mubaya and Mawere 2017). Mubaya and Mawere's concern may be supported by the more recent initiatives to improve the quality of education in Zimbabwe which were undertaken by both the Ministry of Primary and Secondary Education (MoPSE) and the Ministry of Higher and Tertiary Education, Innovation, Science and Technology Development (HTEISTD). In 2014, the MoPSE embarked on an education reform aimed at producing and implementing a competency-based, cultural heritage-driven curriculum. The authors of this paper's participation as consultants in their fields of specialty, enabled them to witness that the cultural heritage authorities (owners of indigenous knowledge and expertise) were excluded in the workshops that were held in developing the new curriculum and this reflects on the envisioned futility of the endeavour owing to the fact that all the participants happened to be graduates of the colonial education system. The claim that no one should be called educated unless they are at one with the culture that spawned them and which hosts them (Magwa 2019), therefore, stands true. What is required in the new system of education is a kind of cultural exorcism which should detoxify Africans in general and Zimbabweans in particular with the ultimate goal of utilising their cultural heritage to sustain their livelihoods (Ibid). The initial mention of a heritage-driven system in higher and tertiary education in Zimbabwe is contained in the 2019 revised mission statement for HTEISTD which reads: A heritage based higher and tertiary education, science and technology development for a competitive, industrialised and modernised Zimbabwe by 2030. We observe that these initiatives point to the thinking behind the liberation of the mental space of Western educated Zimbabweans. As such, Zimbabwe's more recent education reforms represent the voice of the indigenous people's agency to establish an education system not only founded on indigenous knowledge systems, but also one that will add value to their lives. Suffice to say: 
There is a need to include alternative paradigms in education that are less positivistic, Eurocentric and individualistic than what has become the norm today. A combination of valuable attributes of the positivistic and non-linear organic systems of knowledge might create the ideal framework to foster an ethos of holistic, transformative and emancipatory educationa experience for all. (Oviawe 2016).

The constructed $A Z H R$ is one such an intersubjective and interdisciplinary framework that is meant to foster through an educational system the relationships between Zimbabweans, and indeed Africans and the universe upon which they live, work, profit, derive meaning and sustenance, and frame their everyday lives (Milbourne and Hill 2011).

\section{Sustainability through $A Z H R$ Model}

The claim of the familiar concern for conserving cultural heritage, especially that of oral traditions, focusing on documentation and archiving has been highlighted by the UNESCO 2003 Convention and hailed by many academics from across the disciplinary divide. However, the Convention's shortcomings are that the listing of endangered intangible cultural heritage and masterpieces will note their worthiness for international support, but would neither save them nor necessarily occasion action plans adequate to sustain them, and also that the actions the Convention proposes miss the larger, holistic aspect of culture - the intrinsic and complex web of meaningful social actions (Kurin 2004). The authors' lived experience support these deficiencies. They toured the Great Zimbabwe Monuments several times before and after Zimbabwe attained its independence in 1980. The tours included witnessing the entertainment offered by indigenous musical arts performing experts at the African village. We donated our tokens of appreciation each time we attended the performances, but we noticed that some tourists, including those who used video cameras to capture the artistry, did not give anything in appreciation of what they consumed. This exploitative move led us to focus on the plight of the vulnerable performers and their creative intellectual property. Our regular engagements with the performers resulted in Mushipe, the leader of one of the dance groups, embracing our gesture of embarking on a project for empowering them in order that they sustain themselves through the richness of their inheritance. As such, the planning for the project which began in March 2015, has since become a community Trust registered as the Dzimbadzamabge Cultural Heritage Enterprise Institute (DCHEI). While the process of securing a suitable location for the Institute was under way, we assisted the Dzorira Ngoma Dance Troupe under Mushipe's leadership to choregraph their indigenous dances to suit stage performances, after which they participated in the Chibuku Neshamwari Traditional Dance Annual Competitions and won first prizes at Provincial level for four consecutive years from 2016-2019. In May 2018, the Trust hosted a national festival so as to make it become visible. The festival's far-reaching influence drew to the Institute scholars and academic researchers, curriculum developers, tourists and bus-fulls of school children as well as college and university students. The prize money, the money from fees for touring and receiving instruction together with donations of food from community members have enabled the construction of some structures that presently stand on the Institute site. Mushipe is the Chairperson of the Institute's Board of Trustees which is the Responsible Authority, that is made up of the community members to the project who are in good standing. We, the authors, are the Principal Researchers for the Institute.

The Institute's vision: To be the most inspirational, transformative and rewarding cultural heritage institute in shaping the future; resonates with the heritage bearers' agency to have their voice uplifted through education as a tool for economic sustainability. The three goals and objectives of the African Union Agenda 2063's strategic framework for inclusive and sustainable development; Africa with a strong cultural identity; An African whose development is people driven, relying on the potential offered by African people; and An Africa as a strong, united, resilient and influential player and partner, comprehensively reflect the views of the Karanga of the Dzimbadzamabge community. The African Union as the voice of its populace, envisions a visible, supple and self-reliant continent. We believe that the initial step on a trajectory to operationalise this vision is the transformation and reconstruction of education, which transformation and empowerment challenges the normalisation of Western discourses (Chowdhury 2019). To this end, we offer an AfriZimcentric Cultural Heritage Resilience model which embodies a holistic approach to imparting indigenous Zimbabwean cultural civilisation. The features on the Institute site incorporate caves, thickly grown vegetation with a lot of herbs, a field for growing small grain crops, built environment embodying the infrastructure of an indigenous Karanga homestead, community shrine, open-air performance venues, children's play centres and other buildings which will serve as classrooms, working spaces and archives. Accordingly, the site provides a conduce environment for conveying the holistic cultural heritage of the innovative and iconic Dzimbadzamabge Institute in ChiKaranga and the equivalent translations in other Zimbabwean ethnic languages. The involvement of other cultural knowledge owners and artefacts experts in the Dzimbadzamabge Institute activities guarantees the replication of the project to ethnic communities other than the Karanga Dzimbadzamabge community.

\section{Conclusion}

This chapter explored African life experience so as to disclose the connectivity, not only of tangible and intangible cultural heritage in African thought and practice, but also of heritage and community sustainability. The inclusion of the description of the Western epistemology was premised on account of the historical dominance of the narrowly focused Western epistemology on the inclusive indigenous African philosophy and cosmology which resulted from the colonisation of African nations by Europe. Notwithstanding its meagre benefts, this hegemony culminated, not only in the marginalisation of African cultural heritage, but also in the exploitation of the vulnerable indigenes.

The wide ranging and far reaching adverse effects of the British colonial power on the indigenous people of Zimbabwe, particularly the Karanga with whom the authors have had much contact through their research has led to the birth of the 
AfriZimcentric Heritage Resilience framework; an emancipatory cultural heritage trajectory targeted at the Karanga of the Dzimbadzamabge rural community. As is the nature of transformation and reconstruction, the intial steps to this path were ridden with challenges of skepticism on the part of community members as custodians of their cultural inheritance working with the researchers (authors) who are highly trained in the conventional scientific knowlegde system. By employing the idea of affording the Dzimbadzamabge community members to actively decide on and engage with the process (Apaydin 2020) of developing the $A Z H R$, an exploratory, experimental framework for the Trust as well as identifying and constructing the Institute site, the authors managed to help the ocmmunity to spearhead the project.

The AZHR framework resonates with the community's opinion on their strategy for liberating their minds through heritagebased education imparted through indigenous languages as media of instruction in order to empower themselves mentally, physically, socially, politically, economically, spiritually and emotionally. The community's fascination with the scope and reach of framework acts as a motivating factor for the advancement of heritage education for community and nation building. The projected acquisition of higher education academic qualifications in African indigenous knowledge systems coupled with exit entrepreneurial competences to be granted by DCHEI ought to be enhanced through further research in community engagement, heritage education curriculum deleopment and implementation, cultural industries, resource management and capacity building programmes which will anchor the Institute and its subsidiary entities.

\section{References}

[1].Abungu, G. (2019). Africa's Rich Intangible Heritage: Managing a Continent's Diverse Resources. In T. J. Cooley (ed.), Cultural Sustainabilities: Music, Media, Language, Advocacy. University of Illinois Press.

[2].African Union (2013). Agenda 2063: The Africa We Want. AU 50 th Anniversary Solemn Declaration. Available at: https://au.int/en/agenda2063/overview Accessed 25 May 2020. Apaydin, V. (2020). The Interlinkage of cultural memory, heritage and discoursesof construction, transformation and destruction. In V. Apaydin Critical Perspectives in Cultural Memory and Heritage: 13 - 29.

[3].Brush, S G. (2019). Scientific Revolution. Encyclopaedia Britannica. Available at: https://www.britannica.com/science/Scientific-Revolution Accessed 27 March 2020. Chakawa, B. (2019). Indigenous musical arts expert. Interview by authors, Dzimbadzamabge community, Masvingo.

[4].Chowdhury, R. (2019). Transformation and Empowerment through Education:

[5].Reconstructing Teaching and Learning. Abingdon Oxon: Routledge.

[6].Dengu, R. (2020). Herbalist. Interview by authors, Dzimbadzamabge community, Masvingo. Gad, C. Aand Ribes, D. (2014). The Conceptual and the Empirical in Science and Technology Studies. Science, Technology and Human Values, 39(2), 183 - 191.

[7].Higgs, P. (2008). Towards an Indigenous African Educational Discourse: A Philosophical Reflection. International Review of Education, 54(3/4), 445-458.

[8].Hountondji, P. J. (2002). Knowledge appropriation in a postcolonial context. In C. A. O.

[9]. Hungwe, K. (1994). Educational Policy in African colonial Contexts: The Case of Instructional Media in Southern Rhodesia (1930 - 1980). African Study Monographs, 15(1), 1 - 36.

[10]. Idang, G. (2015). African culture and values. Phronimon, 16(2), 97-111.

[11]. Tanzi, V. (1998). Corruption Around the World: Causes, Consequences, Scope and Cures. International Monetory Fund. IMF Working Paper.

[12]. Kurin, R. (2004). Safeguarding Intangible Cultural Heritage in the 2003 UNESCO

[13]. Convetion: A critical appraisal. UNESCO General Conference. Oxford: Blackwell Publishing.

[14]. Mageza, L. (1997). African Religion: The Moral Traditions of Abundant Life. New York:

[15]. Orbis Books.

[16]. Magwa, W. (2019). African Culture and Heritage in Africa Volume 1. Gweru: Mambo Press.

[17]. Mawere, M and Awuah-Nyamekye, S (eds). (2015). Between Rhetoric and Reality: The State and Use of Indigenous Knowledge in Post-Colonial Africa. African Books Collective. Mbiti, J. S. (1969). African Religions and Philosophy. Ibadan: Heimann Educational Boleswa.

[18]. Mendoza R, Baldiris S and Fabregat R. (2015). Framework to Heritage Education using Emerging Technologies. Procedia Computer Science, 75: 239 - 249.

[19]. Milbourne, K. E and Hill, S. (2011). Excavation, Accumulation and Preservation in the African Landscape. Seed Grant Application for Joint Smithsonian Institution and University of Maryland, College Park.

[20]. Mlambo, A. S. (2014). A History of Zimbabwe. Cambridge University Press.

[21]. Msemwa, P. (2005). Community's perception towards heritage resources: Conflicting interest. In B. Mapunda and P. Msemwa (eds) Salvaging Tanzania's Cultural Heritage: 236 - 242.

[22]. Mubaya, T. P. And Mawere, M. (2017). Cultural Heritage is Our Right, Our Dignity: Rethinking the Concept and Use of Heritage in Zimbabwe. In M Mawere, T R Mubaya and J Mukusha (eds) The African Conundrum. Online publication accessed June 22, 2020.

[23]. Mugabe, M. (2019). Acting Chief. Interview by authors, Mugabe Chiefdom, Masvingo.

[24]. Muller, S. (20212). 'Two Ways': Bringing Indigenous and Non-Indigenous Knowledge Together. In J. K. Weir (ed) Country, Native Title and Ecology. $59-80$.

[25]. Munjeri, D. (2004). Tangible and Intangible Heritage: from difference to convergence.

[26]. Oxford: Blackwell Publishing. 
[27]. Mushipe, C. D. (2020). Spirit medium. Interview by authors, Mugabe Chiefdom, Masvingo. Nickles, T. (2019). Scientific Revolutions. Stanford Encyclopaedia of Philosophy. Available https://plato.stanford.edu/cgibin/encyclopaedia/archinfo.cgi?entry=scientific-revolutions Accessed 23 June 2020.

[28]. Nyamnjoh, F B. (2001). Delusions of development and the enrichment of witchcraft discourses in Cameroon. In H. Moore and T. Sanders (eds), Magical interpretations material realities, modernity, witchcraft and occult in postcolonial subjectivity in Africa. London: Routledge.

[29]. O'Donoghue R, Shava S and Zazu C. (eds). (2013). African Heritage Knowledge in the context of Social Innovation: Learning contributions of the Regional Centres of Expertise on Education for Sustainable Development. Yokohama: United Nations University Institute of Advanced Studies.

[30]. Olupona, J. (2015). The Spirituality of Africa. Harvard University Press.

[31]. Parker, F. (1960). Life and Education in Southern Rhodesia. The Phi Delta Kappan, 41(4),

[32]. 174-179.

[33]. Accessed 5 June 2020.

[34]. Oviawe, J. O. (2016). Introduction: How to rediscover the Ubuntu paradigm in education. International Review of Education, 62(1): 1 - 10.

[35]. Rettova, A. (2016). African philosophy as a radical critique. Journal of African Cultural Studies, $28(2), 127$ - 131.

[36]. Rutsate, J. (2020). Generational memory narration. Bikita District, Masvingo Province. Sub-Saharan. The SAGE International Encyclopaedia of Music and Culture, 78-80. (2019). Africa [37]. (2010). Mhande dance in kurova guva ceremony: An enactment of Karanga spirituality. Yearbook for Traditional Music, 42: 81 - 99.

[38]. Rutsate, S. H. (2020). Generational memory narration. Bikita District, Masvingo Province.

[39]. Stanford Encyclopaedia (2020). Epistemology. Stanford Encyclopaedia of Philosophy.

[40]. Available at: https://plato.stanford.edu/entries/epistemology Accessed 17 May 2020.

[41]. Stroll. A. (2020). Epistemology. Encyclopaedia Britannica.

[42]. https://www.britannica.com/browse/Philosophy-Religion Accessed 17 May 2020.

[43]. Transparency International Corruption Perceptions Index. (2019). Internationa AntiCorruction Day. transparency.org/en/ Accessed 7 October 2020.

[44]. UNESCO. (2019). Reconstructing Africa's history, freeing it from racial prjudices ensuing from slave trade and colonization, and promoting an African perspective. General History of Africa. en.unesco.org/general-history-africa Accessed 30 September 2020.

[45].___ (2003). United Nations Educational, Scientific and Cultural Organization Convention for the Safeguarding of Intangible Cultural Heritage.

[46]. United Nations. 2015. Department of Economic and Social Affairs Millenium Development Goals Report. sdgs.un.org/topics/africa Accessed 5 October 2020.

[47]. Wamue, G. N. (2001). Our Indigenous Shrines through Mungiki. African Affairs, 100(400), 453 - 467.

[48]. West, A. (2014). Ubuntu and Business Ethics: Perspectives and Prospects. Journal of Business Ethics, $121(1)$ : 47 61.

[49]. World Economic Forum. (2019). Corruption costs development countries \$1,26 trillion every year - yet half of EMEA think it's acceptable.

[50]. weforum.org/agenda/2019/corruption-global-problem-statistics-cost/ Accessed 6 October 2020.

[51]. World Health Organization. (2016). Atlas of African Health Statistics 2016: Health situation analysis of the African Region. Global Health Observatory (GHO)-Data repository. Available at: http://apps.who.int/gho/data/view.main Accessed 30 April 2020.

[52]. Zimunya C T, Gwara J and Mlambo O B. (2015). The Feasibility of Ubuntu Ethic in a Modernised World. Journal of African Foreign Affairs, 2(1/2): 5 - 26. 